\title{
New trenching results along the İznik segment of the central strand of the North Anatolian Fault (Turkey): an integration with preexisting data
}

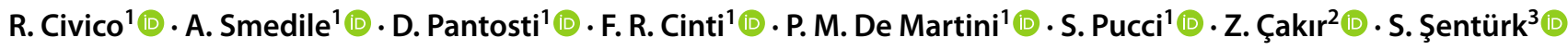

Received: 9 November 2020 / Revised: 17 March 2021 / Accepted: 19 March 2021 / Published online: 4 April 2021

(c) The Author(s) 2021

\begin{abstract}
This paper provides a new contribution to the construction of the complex and fragmentary mosaic of the Late Holocene earthquakes history of the İznik segment of the central strand of the North Anatolian Fault (CNAF) in Turkey. The CNAF clearly displays lower dextral slip rates with respect to the northern strand however, surface rupturing and large damaging earthquakes $(M>7)$ occurred in the past, leaving clear signatures in the built and natural environments. The association of these historical events to specific earthquake sources (e.g., Gemlik, İznik, or Geyve fault segments) is still a matter of debate. We excavated two trenches across the İznik fault trace near Mustafali, a village about $10 \mathrm{~km}$ WSW of İznik where the morphological fault scarp was visible although modified by agricultural activities. Radiocarbon and TL dating on samples collected from the trenches show that the displaced deposits are very recent and span the past 2 millennia at most. Evidence for four surface faulting events was found in the Mustafali trenches. The integration of these results with historical data and previous paleoseismological data yields an updated Late Holocene history of surface-rupturing earthquakes along the İznik Fault in 1855, 740 (715), 362, and $121 \mathrm{CE}$. Evidence for the large M7 + historical earthquake dated $1419 \mathrm{CE}$ generally attributed to this fault, was not found at any trench site along the İznik fault nor in the subaqueous record. This unfit between paleoseismological, stratigraphic, and historical data highlights one more time the urge for extensive paleoseismological trenching and offshore campaigns because of the high potential to solve the uncertainties on the seismogenic history (age, earthquake location, extent of the rupture and size) of this portion of NAFZ and especially on the attribution of historical earthquakes to the causative fault.
\end{abstract}

Keywords North Anatolian Fault Zone · İznik fault · Strike-slip · Paleoseismology

\section{Introduction}

The North Anatolian Fault Zone (NAFZ) is an east-west trending, $\sim 1500 \mathrm{~km}$ long right-lateral strike-slip fault that extends from the northern Aegean Sea to the Karliova triple junction in Eastern Turkey (Barka 1992; Sengör et al. 2005; McKenzie 1972; Saroglu et al. 1992; Emre et al. 2018 -inset of Fig. 1a) and accommodates the relative motion of the

R. Civico

riccardo.civico@ingv.it

Istituto Nazionale di Geofisica e Vulcanologia, Roma, Italy

2 Faculty of Mines, Department of Geological Engineering, Istanbul Technical University, Istanbul, Turkey

3 Istanbul Technical University, Eurasia Institute of Earth Sciences, Istanbul, Turkey
Eurasian plate and Anatolian block with a velocity of more than $20 \mathrm{~mm} /$ year (McClusky et al. 2000).

To the east the NAFZ marks a narrow fault zone (Barka 1996) but becomes more complex to the west as it enters the Sea of Marmara region, splaying into different fault segments, 40-150 km-long (Fig. 1a). In Northwest Anatolia, the NAFZ comprises three sub-parallel strands (Fig. 1a): the northern strand (NNAF) accommodates most of the total right-lateral slip of the zone (14-24 mm/year, Armijo et al. 2002; Flerit et al. 2003, 2004; Pantosti et al. 2008; Pucci et al. 2008; Meade et al. 2002); the central (CNAF) and southern (SNAF) strands accommodate together the remaining part of the slip (2-5 mm/year and 3-6 mm/year, respectively; Armijo et al. 2002; Flerit et al. 2003; McClusky et al. 2000; Meade et al. 2002; Reilinger et al. 1997, 2006; Hergert and Heidbach 2010; Hergert et al. 2011; Selim et al. 2013). In contrast with the NNAF, which runs in the Marmara Sea, 


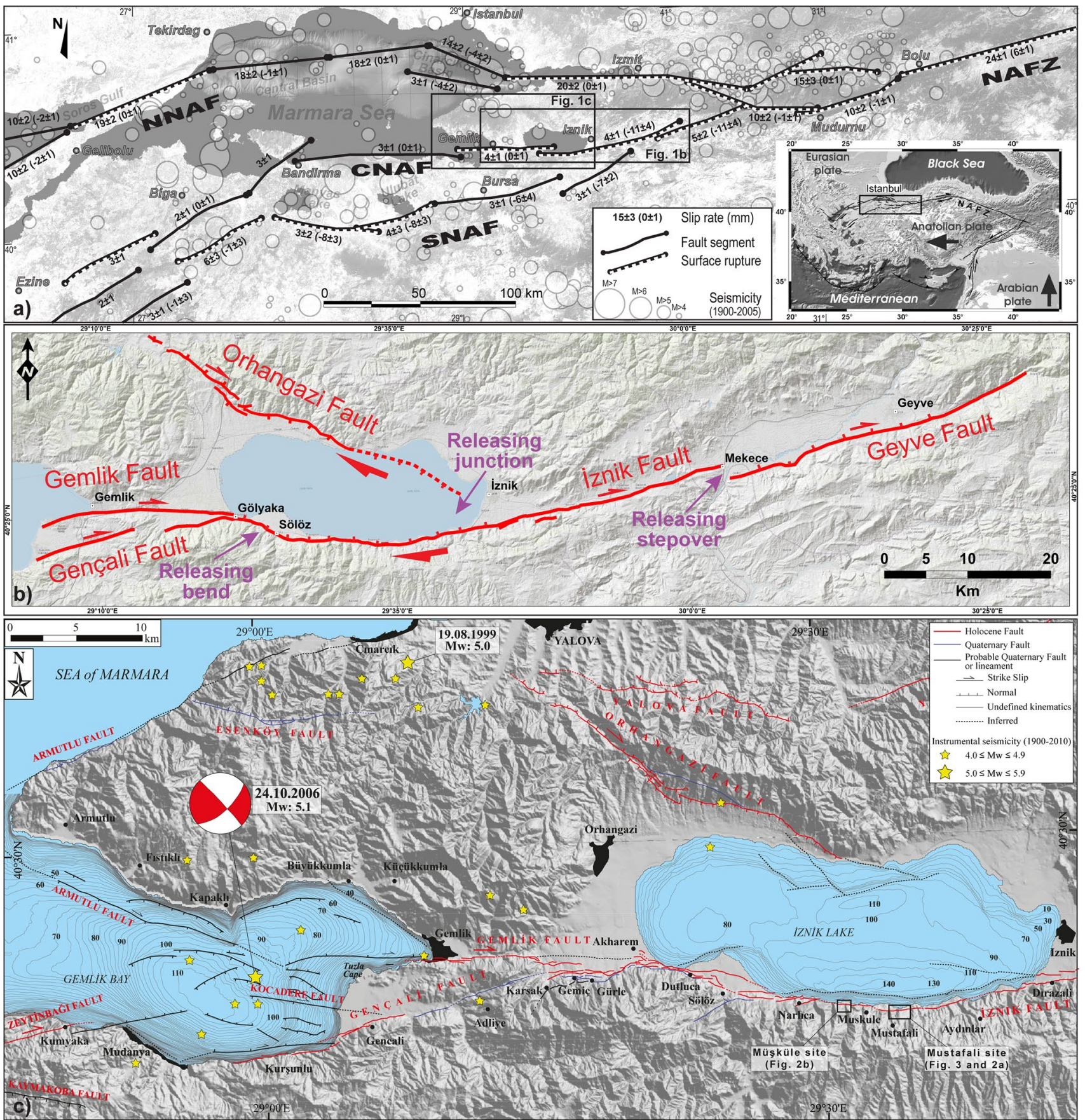

Fig. 1 a Active faults of the North Anatolian Fault Zone and its three branches along the Marmara region (modified from Murru et al. 2016). Earthquakes with $M>4.0$ from 1 January 1900 to 31 December 2006 are reported (AFAD 2020). The slip rates along the strike and dip of the main segments are also shown (after Murru et al. 2016). b Map of the İznik Fault showing the main geometrical discontinuities with the nearby fault segments. c Neotectonic map of

the CNAF and SNAF strands run mainly inland and bound several Quaternary basins.

Slip partitioning, combining predominant right-lateral and secondary vertical components, occurs along the CNAF
Gemlik and its vicinity (on land faults from Emre et al. (2011, 2018); Gemlik bay faults and bathymetry from Kuşçu et al. 2009; İznik Lake bathymetry from Ikeda et al. 1991; İznik Lake underwater faults modified from Gastineau et al. 2021; seismological data from Kalafat et al. 2011). Modified from Özalp et al. (2013). The location of the study sites is reported

and SNAF reaching values of up to $11 \mathrm{~mm} / \mathrm{year}$ (Flerit et al. 2003, 2004; Meade et al. 2002; Selim et al. 2013). The CNAF branches from the NAFZ west of the Mudurnu segment and, before entering the southern Marmara Sea, 
comprises three main fault segments: Geyve, İznik and Gemlik, 40-57 km long (Emre et al. 2011, 2018). In a very simplified framework, these segments are seen as separated by right stepovers, where pull-apart basins had developed; these would function as geometrical barriers to rupture propagation (e.g., Koçyiğit 1988; Emre et al. 1998; Özalp et al. 2013; Murru et al. 2016). However, recent detailed mapping (e.g., Emre et al. 2011, 2018) has highlighted that the fault zone setting is more complex especially for the İznik Fault. On one side, the İznik Fault, that to the east was aligned with the rest of the CNAF striking $\mathrm{N} 80^{\circ}-85^{\circ} \mathrm{E}$, approximately at the longitude of İznik, changes to a $90^{\circ}-95^{\circ} \mathrm{E}$ strike (Öztürk et al. 2009). This change is possibly driven by the releasing junction (sensu Christie-Blick and Biddle 1985) with the Orhangazi Fault to the north (Fig. 1b) that also results in an important normal component of the fault kinematics in the west (Ikeda et al. 1991). On the other side, the segment boundary between the İznik and Gemlik segments near Sölöz, is rather complex with several traces forming a continuous broad releasing bend $(\sim 5 \mathrm{~km}$ long and $\sim 2 \mathrm{~km}$ wide) that links the stepover invoked to act as a barrier to the rupture propagation (e.g., Koçyiğit 1988; Emre et al. 1998; Özalp et al. 2013) (Fig. 1b, c). This fault setting would open questions on the role of segment boundaries as permanent barriers to earthquake ruptures.

Although the CNAF and SNAF strands have lower slip rates with respect to the NNAF, several large historical and instrumental earthquakes (up to Ms 7.4) can be related to specific segments that produced remarkable surface ruptures in the past and that hit highly populated towns such as Bursa, İznik, and Biga (McKenzie 1978; Barka and Kadinsky-Cade 1988; Taymaz et al. 1991; Guidoboni et al. 1994; Ambraseys and Jackson 1998; Ambraseys 2002; Guidoboni and Comastri 2005; Kürçer et al. 2008) (Fig. 1a).

Historical catalogues (e.g., Ambraseys and Finkel 1991; Guidoboni et al. 1994; Ambraseys 2009) report several damaging earthquakes affecting the town of İznik (former Nicaea) and surroundings areas during the past 2 millennia (e.g., 32, 121, 362, 368, 715, 740, 1065, 1419, 1855, 1860, $1863,1875$ and $1893 \mathrm{CE})$. While some of these events are generally associated with the NNAF, others affected more specifically the İnik area and may have nucleated on the CNAF.

Large earthquake occurrence along the CNAF were also confirmed by several paleoseismological trenches performed on this fault strand (e.g., Ikeda et al. 1989, 1991; Honkura and Işikara 1991; Yoshioka and Kusçu 1994; Uçarkus 2002; Doğan, 2010; Özalp et al. 2013).

However, although the Marmara region is one of the seismic areas with the best fault data and the richest records of historical seismicity in the Mediterranean, the correlation between historical events and source faults along the CNAF (e.g., Gemlik, İznik, or Geyve fault segments) is still a matter of live debate. Thus, to contribute with one more tile to the earthquake history along the CNAF, we conducted a geomorphologic and paleoseismic campaign along the western portion of the İznik Fault (Fig. 1b,c).

\section{Paleoseismological investigations in the western portion of the İznik Fault}

\subsection{The fault trace}

The İznik fault trace is dominated by a prominent faultrelated morphology consisting of up to 120-m-high scarp, related also to long-lasting and persistent vertical component of the surface faulting. Along the 56-km-long İznik fault segment, offset drainages, sag ponds, fresh fault scarps and shutter ridges testify its Quaternary-Holocene activity (Tsukuda et al. 1988; Honkura and Işıkara 1991).

The western portion of the İznik fault trace reveals a high internal complexity probably related to the releasing joint with the Orhangazi Fault near İznik (Fig. 1). To the west of this joint, the İznik Fault has a change in strike of about $10^{\circ}$ and a substantial increase of vertical component. In general, this part of the fault appears as a compound zone of right-stepping subsections, running on-shore at the base of a sharp mountain front of the southern fault block. The present deformation zone is represented by two main fault strands; one at the base of the mountain front, the other, several tens of meters to the north, involving Holocene and Late Pleistocene deposits of the plain and showing larger complexity as well as multiple splays (Fig. 2).

The north-flowing drainage system of this area shows spectacular right-handed deflections of low-stream power reaches that cross at high angles the fault trace at the outlet of the range front, where they build an alluvial bajada prograding over the İznik lake shoreline. As a result, the creeks are dragged along the fault line and their downstream reach shifts away from the flow axis of the corresponding upstream reach.

\subsection{Cumulative geomorphic offset}

By reconstructing the original geometry of the streams cutting the fault zone, it is possible to measure the cumulated offset along the fault. Figure 2 shows two examples from the Mustafali and Müşküle areas (see Fig. 1c for location). At the Mustafali site, the fault zone is formed by at least three fault traces that offset the Kalaba creek forming two welldefined right-handed deflections of $12 \pm 4 \mathrm{~m}$ and $14 \pm 5 \mathrm{~m}$, respectively (Fig. 2a). Approximately $4 \mathrm{~km}$ west of Mustafali, at the Müşküle site the Anibar creek shows a cumulative horizontal right-lateral deflection of about $72 \pm 16 \mathrm{~m}$ (Fig. 2b). The timing of the last depositional phase (prior 

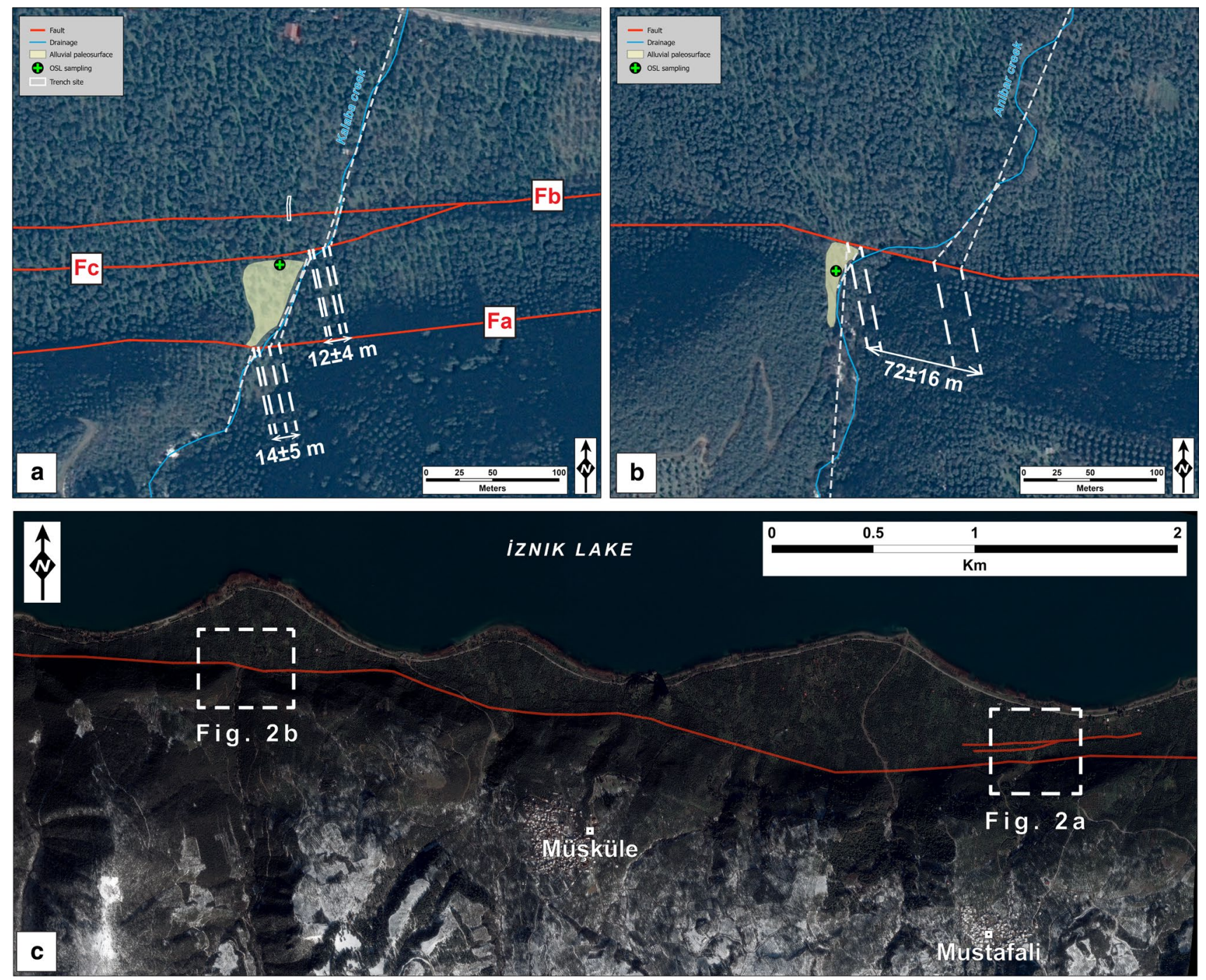

Fig. 2 Stream (blue solid line) deflection measurements at a Mustafali and b Müşküle sites. Dashed lines indicate the possible projections on the fault (red solid line) of the stream channels to serve as cut-offs. Yellow areas represent the remnant of an alluvial fan sur-

to stream entrenchment) that likely marks the onset of the creek deflection can be used to estimate a slip rate for this portion of the fault. OSL dating of remnants of the alluvial deposits found on abandoned river terraces provides ages of faulting at the two sites: $1457 \pm 112$ cal year BP at Mustafali (MSF-2-Table 1) and 7193 \pm 503 year BP at Müşküle (MSK-1-Table 1). Even if aware of the large uncertainties that may affect the results because based on a single dating per site, we attempted the calculation of the dextral slip rate at these sites resulting in a minimum $8.5 \pm 3.4 \mathrm{~mm} /$ year and $10.3 \pm 3.0 \mathrm{~mm} /$ year, respectively. These values appear too high considering the general framework of faults motion from GPS data, thus, unfortunately they cannot be taken as reference for the İznik Fault. Beside the limited age information and the intense anthropization of the area, other factors face. Green cross in black circle indicates the OSL sample locations. See Fig. 1c for locations. c Simplified geometry of the İznik Fault in the vicinity of the Mustafali and Müşküle sites

that may have affected these estimates are related to a non rectilinear initial geometry of the stream entrenchment or to the effect of the vertical component that may emphasize the offset.

\subsection{Trenching}

Intense agricultural modification of the study area made particularly difficult to find sites suitable for paleoseismological investigations; plowing and agricultural exploitation since historical times has, in most of the cases, destroyed the upper part of the stratigraphy decreasing the possibility to study the signatures of very recent earthquakes. Another limitation to paleoseismological trenching in the area is the presence of important cumulated fault scarps that diminishes 
Table 1 Results of the Optically Stimulated Luminescence (OSL) samples analysis performed at the PH3DRA laboratories

\begin{tabular}{lllll}
\hline Sample & $\begin{array}{l}\text { Mean volume } \\
\text { water content } \\
(\%)\end{array}$ & $\begin{array}{l}\text { Equivalent dose } \\
\text { (Grays) }\end{array}$ & $\begin{array}{l}\text { Dose rate } \\
\text { (mG/a) }\end{array}$ & $\begin{array}{l}\text { OSL age } \\
\text { (year BP) }\end{array}$ \\
\hline MSF-2 & 31.3 & $3.4 \pm 0.18$ & $2.34 \pm 0.13$ & $1457 \pm 112$ \\
MSK-1 & 41.8 & $14.1 \pm 0.80$ & $1.96 \pm 0.08$ & $7193 \pm 503$ \\
\hline
\end{tabular}

Samples were collected in the upper layers composing the alluvial surfaces downcut by deflected creeks (i.e., river terraces). A standard protocol used routinely for sediments dating was applied. ED is obtained from OSL emissions evaluated with the Single-Aliquot Regenerative-dose (SAR) protocol (Murray and Wintle 2000, 2003) on coarse-grained quartz inclusions extracted from the sample (Fuchs and Lang 2001; Carobene et al. 2006; Stevens et al. 2007). Luminescence measurements were performed on small aliquots (Duller 2008) of quartz grains $(100 e 300 \mathrm{~mm})$ and feldspar contamination was checked using IR stimulation (Choi et al. 2009) and the preheat parameters were based on test measurements (Wintle and Murray 2000; Murray and Wintle 2003). All errors are at one sigma except for Equivalent Dose, based on radial plots from the Central Age Model (CAM)

the potential to distinguish the Holocene individual events of deformation from the cumulated one.

Among the very few suitable sites presenting promising stratigraphy, we selected two locations for excavating paleoseismological trenches near the village of Mustafali, one on the left bank of the Kalaba creek flowing to the İznik Lake (trench A) and the other about $350 \mathrm{~m}$ to the east (trench B). Since no evident piercing points to measure individual horizontal coseismic offset were found at the trench sites, we opened only perpendicular excavations crossing the İznik Fault trace. The geology of this area consists mostly of alluvial and lacustrine gravels, sands and clays of the Middle Pleistocene-Holocene İznik and Sölöz formations (Doğan et al. 2014). The Katirli mountain range lying directly south of the İznik Fault is composed of Upper Cretaceous sedimentary rocks and volcaniclastic rocks of Eocene-Oligocene age (Bargu 1982; Yılmaz et al. 1995; Özcan et al. 2012). Slope wash and colluvium are common all along the mountain slope and fault scarp.

\subsubsection{Trench A}

Trench A was located on the left bank of the Kalaba creek across the northern splays of the İznik Fault (Fig. 3a). At this site we attempted the measurement of the slip rate across the central splay of the fault (Fc in Figs. 2a and 3a) as discussed in the previous section. The fault scarp cuts an alluvial fan surface fairly remodeled by farming. The height of the scarp is about $2-2.5 \mathrm{~m}$ (profile A-A', Fig. 3b).

The trench was N-S to NNE-SSW oriented (deviation needed to preserve olive trees), $14 \mathrm{~m}$ long, up to $2 \mathrm{~m}$ deep, and $1.5 \mathrm{~m}$ wide (Fig. 4a). Both walls exposed comparable stratigraphic sequence and structures, thus we present the east wall, only, being the most representative (Fig. 4). The sedimentary sequence is characterized by colluvial and alluvial deposits derived by fan activity. An alluvial coarse gravel fining upwards (unit 8) is found at the bottom of the trench, this is followed by an alternance of fine gravel and sand (unit 7). Between meters 5 and 8, without a lateral continuity, a massive and compact silt with clasts is displayed (unit 6). Upwards, a compact and massive silt with sparse large clasts, ranging in size from 1 to $6 \mathrm{~cm}$ (unit 5), seals the previous units $(6,7$ and 8$)$. A loose sandy layer with planar lamination (unit 4) is overlayed by a gravel deposit (unit 3), limited to the southward and middle portion of the trench. This latter unit also contains angular to sub-angular clasts increasing in size up to $10 \mathrm{~cm}$ southwards. A light hazel to gray silty deposit (unit 2) turns to a dark gray silt (unit 2A) northward. Both units showed an increasing in thickness towards the trench edges and thinning in the middle portion. The whole sequence is buried under a dark brown silty soil (unit 1). In general, trench deposits are weakly to strongly cemented and the lack of developed paleosoils suggested a regular dynamic in the fan development. The scarcity of organic components limited the possibility to establish good chronological constraints for the exposed stratigraphy. However, the available radiocarbon $\left({ }^{14} \mathrm{C}\right)$ dating of the sampled units (Table 2) suggests a young age for the sequence, with the upper meter of the sequence spanning from present (unit $2 \mathrm{~A}$ ) to about 1400 years ago (unit 4).

The sedimentary sequence appears deformed across two fault zones affecting the stratigraphy at different levels and producing a general lowering to the north: F1 between meters 5 and 8, and F2 at meters 12-13 (Fig. 4d).

F1 shows a typical strike-slip style of deformation, with an apparent reverse throw and abrupt changes of thicknesses of the layers across the two sides of the fault zone. It is characterized by two main faults located about $1 \mathrm{~m}$ apart that, based on their geometry, likely join in a single plane a few meters below the trench floor (Fig. 4d). The southern trace displays a positive flower structure where we find suggestions for the occurrence of the two oldest events, labeled as E3 and E4. E4 horizon can be placed at the top of Unit 7. Units 7 and 8 are in tectonic contact along the southernmost fault trace both because of an apparent vertical displacement and a horizontal juxtaposition, whereas the overlying unit 6 appears undeformed (Fig. 4d). Following E4, the deposition started again (units 5 and 6 ) with a small channel flowing in the fault zone (unit 6). E3 cuts the sequence up to the basal part of unit 5 with a thrust style of deformation typical of flower structures. Additional evidence for multiple events along this structure is the greater apparent vertical offset associated with E4 with respect to that for E3.

Along the northernmost fault splay of F1 the observed deformation between meters 7 and 6 extends in the upper 

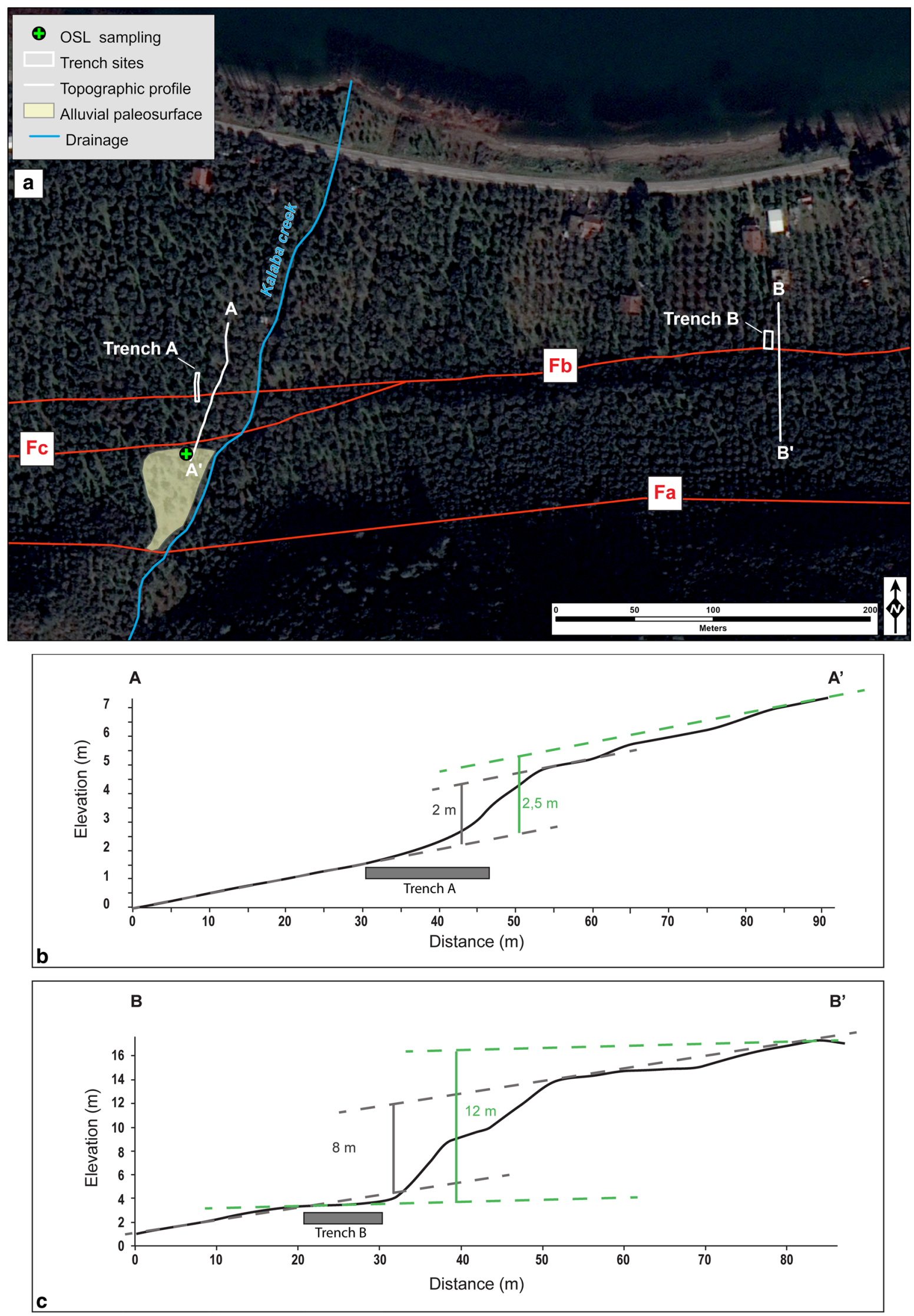
4 Fig. 3 a Pleiades satellite image of the Mustafali site with the location of two trenches opened in 2015 and the simplified trace of the CNAF (red line); the inset shows the southeastern portion of the İznik Lake and the location of the investigated sites. b Topographic profile at trench $\mathrm{A}$ and $\mathbf{c}$ topographic profile at trench $\mathrm{B}$, in green and black maximum and minimum fault scarp vertical offset measurements, respectively

section of the stratigraphy, showing evidence for a younger event labeled as E2 (Fig. 4d). Here, multiple fault branches upper terminate at the base of unit 2 and clearly warped units 4 and 3 that also appear gently back-tilted toward the slope (south-between meters 9 and 2; Fig. 4b, d). This evidence suggests the event horizon for E2 is at the top of unit 3 or at the base of unit 2. Unit 6 is confined in between the two main faults of F1 zone and is offset, sheared, and dragged into the fault plane by both E3 and E2.

Fault zone F2 is composed of sub-vertical fault planes, with difficult traceability in the upper section, and shows a prevalent apparent dip-slip (normal) component, with the northern side down. The youngest event in the trench, labeled E1 (Fig. 4c, d), is set with uncertainty at or near the top of unit $2 \mathrm{~A}$, that appears to be vertically displaced and has a larger thickness in the hanging wall. This indicates that the displacement occurred during its deposition, possibly with an important horizontal component (Fig. 4c). No evidence for the oldest events is found at this fault zone.

In summary, based on these stratigraphic and structural relations, we conclude that this trench contains the evidence for the occurrence of four surface faulting events and set their event horizons in the stratigraphic sequence (red stars in Fig. 4d). Table 2 reports the ages used to set the occurrence of these events. The timing constraints for these events are discussed in Sect. 2.4.

\subsubsection{Trench B}

Trench B was dug across a 10-m-high fault scarp, with a N-S orientation about $350 \mathrm{~m}$ east of the Kalaba creek (Fig. 3a). Because of the abundant vegetation and high slope steepness, we could excavate only the lower portion of the scarp (Fig. 5). Then, it is possible that the trench did not cover the whole deformation zone. A couple of clear decimetric fresh scarplets are visible in the lower portion of the scarp, suggesting recent faulting (Fig. 5). The trench was $9 \mathrm{~m}$ long, up to $2.5 \mathrm{~m}$ deep, and $1.5 \mathrm{~m}$ wide, and exposed a complex lacustrine and continental sedimentary sequence (Fig. 5a). The stratigraphy is composed of lacustrine deposits (unit 4) and slope wash/colluvial sequences (units 2 and 3 ). Unit 4 outcrops at the trench bottom along the whole exposure and has a distinct light hazel color. It was further subdivided in 3 main sub-units: gravels, fine to coarse grained sand and above, cemented and loose calcrete in a sandy matrix (4A-4B-4C in Fig. 5). We do not have any direct dating for the lacustrine basal unit, however according to Benjelloun (2017) it could be older than ca. 4100 year $\mathrm{BP}$, that is the youngest known age for the lacustrine terraces in the Iznik area. On top of unit 4, there is a package of brown to red clay (unit 3), that, between meters 5.5-7.5, includes at the base rounded pebbles in a red sandy matrix (unit 3A). A red-yellowish silt with sand (unit 2) and a soil layer (unit 1) close the sequence at the top. Coarse-grained material derived from the slope is identified within unit 2 , this forms a well-defined wedge-shaped layer of blocks (thicker at the southern edge of the trench, see Fig. 5b). Part of these blocks were found also inside some artificial holes in the west wall (Fig. 5d). Similarly to trench A, the paucity of organic content in sediments made it difficult to have a good chronological control. Based on sample C3 from unit 3 (Table 2), we would assign a minimum age to the postlacustrine sequence of about 2800 years. However, given the position of this sample in a low area at the bottom of the scarp and the ages of the other dated samples in the trench (pot 3 and $\mathrm{C} 4$ ) reworking of C3 is highly possible and thus, the post lacustrine sequence in the trench can be younger and deposited in the past two millennia.

The overall structural setting of the trench is in good agreement with the morphology of the site. Fault zone F1 (meters 0-2, Fig. 5b, e) is located in the middle part of the scarp where a bench interrupts the scarp profile (Fig. 3c) whereas fault zone F2 defines a low graben-like area at the base of the scarp (meters 4-8, Fig. 5c, e). Fault zone F1 is partially exposed at the southern edge of the trench. There, it appears as a main subvertical trace that vertically displaces and strongly shears the lacustrine deposits (unit 4C). In the hangingwall, there is a small graben including a depression (tectonic fissure?) filled by mixed material from the weathered portion of unit 4 (unit 4A) and in part from unit 2. Unit 4 appears strongly and repeatedly deformed in the whole trench by an unknown amount of earthquakes (En, Fig. 5e). In particular, at meter 5 its repeated displacement put in tectonic contact the subunits $4 \mathrm{C}$ and $4 \mathrm{~B}$. Following these events of deformation, the slope-derived deposition started blanketing the lacustrine deposits initially at the bottom of the scarp (unit 3).

Fault zone F2 is located in the northern part of the trench and comprises multiple faults producing the downthrown of all the sequence and in particular of units 4 and 3 . The multiple splays of F2 form a graben-like shape in correspondence with the base of the scarp with strong shearing of deposits of unit 4 . The main throw is recorded at meter 4 along a fault plane that could be traced up to the surface, in coincidence of an inflection of the ground. Similarly, at meters 6-7, a fault plane reaches the top where a change of the scarp slope occurs along with the thinning of the upper soil. This evidence is used to infer the most recent event exposed in this trench, labeled E1 (Fig. 5e). 

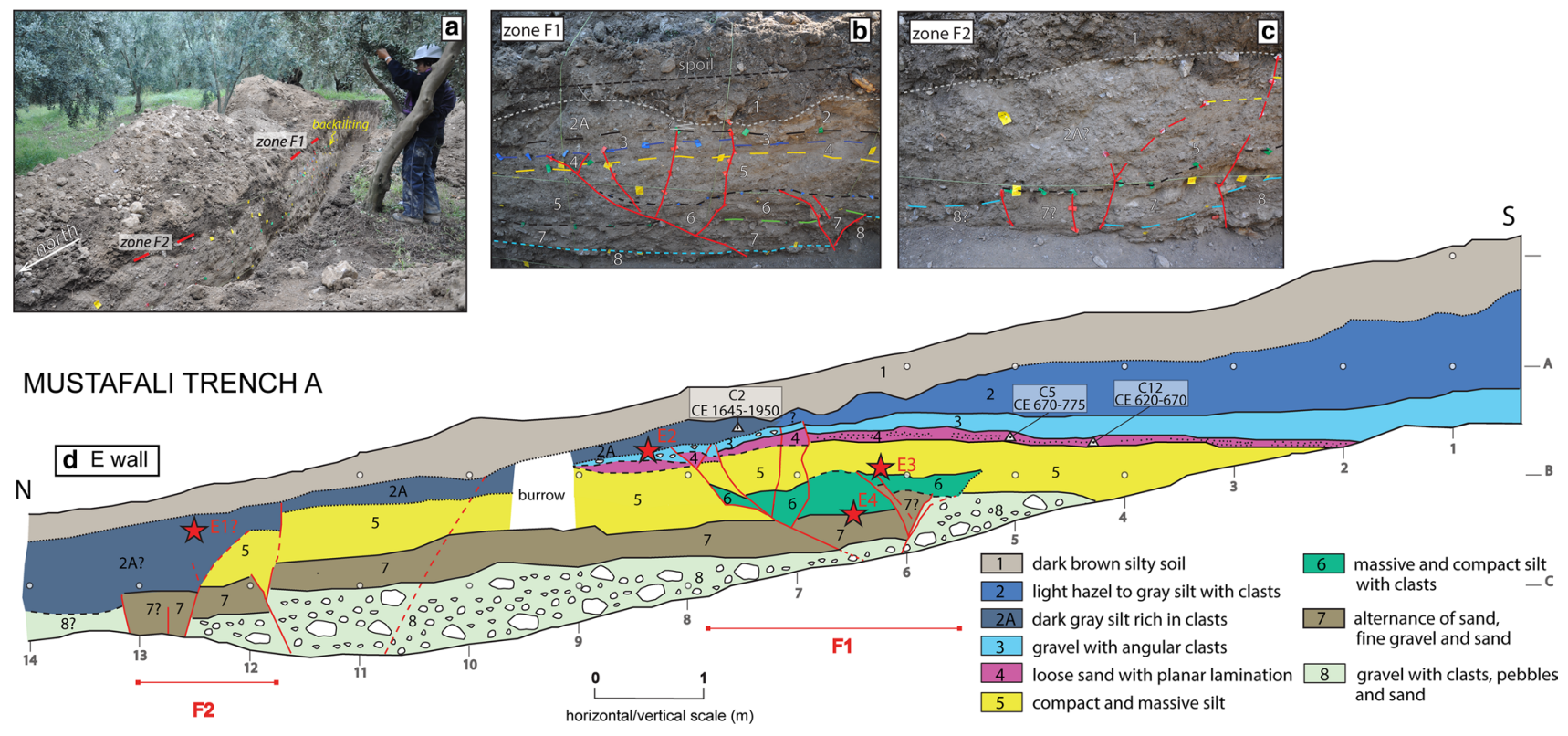

Fig. 4 Mustafali site-Trench A. a View of the trench excavation. b, c Photos of the two fault zones (1-m grid square for scale on the walls). d Log of the eastern wall from a 1:20 field logging. Triangles indicate radiocarbon samples, calibrated ages in the rectangles
(Table 2). Red stars indicate location of event horizons (ground surfaces at the time of surface faulting earthquakes) labeled E1 to E4, starting from the most recent

Table $2{ }^{14} \mathrm{C}$ and $\mathrm{TL}$ ages of the samples collected in the trenches

\begin{tabular}{|c|c|c|c|c|c|c|c|}
\hline Trench\#/unit \# & Sample code & Lab code & Sample material & $\delta 13 \mathrm{C}$ & $\begin{array}{l}\text { Conventional Age } \\
\text { (before } 1950=\text { B.P.) }\end{array}$ & Calibrated age $(2 \sigma)$ & $\begin{array}{l}\text { Probability } \\
\text { distribution }\end{array}$ \\
\hline Trench A/ 2A & $\mathrm{C} 2$ & Beta-425864 & Charcoal & -22.6 & $220 \pm 30$ & $\begin{array}{l}\text { CE 1645-1680 } \\
\text { CE 1735-1800 } \\
\text { CE 1935-post } 1950\end{array}$ & $\begin{array}{l}0.375 \\
0.508 \\
0.119\end{array}$ \\
\hline Trench A/ 4 & C5 & Beta-425868 & Charcoal & -25.7 & $1270 \pm 30$ & CE 670-775 & 1.000 \\
\hline Trench A/ 4 & $\mathrm{C} 12$ & Beta-425865 & Charcoal & -22.2 & $1380 \pm 30$ & CE 620-670 & 1.000 \\
\hline Trench B/ 2 & $\mathrm{C} 4$ & Beta-425867 & Charcoal & -24.5 & $1490 \pm 30$ & CE 540-640 & 1.000 \\
\hline Trench B/ 3 & C3 & Beta-425866 & Charcoal & -26.9 & $2450 \pm 30$ & BCE 760-410 & 1.000 \\
\hline Trench\#/unit \# & \multicolumn{2}{|c|}{ Sample code } & Lab code & & $\delta 13 \mathrm{C}$ & Age TL (before 2016) & Age \\
\hline Trench B/ 4 A & Pot3 & $\mathrm{Pc}$ & Potte & & $1680=$ & & CE 216-456 \\
\hline
\end{tabular}

The lowest graben area between meter 5.5 and 8 is filled by a wedge shaped deposit made of loose rounded pebbles in a sandy matrix (unit 3A). This deposition likely followed a faulting event, infilling the collapsed area with new scarp derived material (i.e., post event deposit). The base of unit $3 \mathrm{~A}$ marks the event horizon of the oldest individual event recognized in this trench, labeled E4. The location of E4 is also supported by the upper termination of some faults. At F2 units 4 and 3A were successively faulted along multiple sub-vertical fault traces both with vertical and lateral motion. This deformation is associated with the occurrence of E3 and results in a further deepening of the graben that was successively infilled and buried by the upper part of unit 3 . Possible evidence for E3 in F1 is found at meter 1.5, where a ca. $50 \mathrm{~cm}$ wide-depression, filled by a mix of reworked sediments (R4A mainly from lacustrine unit 4A) and manmade materials (tiles and pottery), is very likely a tectonic fissure. A fire remnant on top of it and new slope derived material blanketing the whole scarp (unit 2) represent a possible post E3 deposition. Then, the entire sequence was deformed by a younger event (E2) revealed by several F2 splays that terminate within unit 2. The layer of blocks on top of unit 2 at F1 and in the northern part of F2, is interpreted as a coseismic rock fall related to the shaking of E2 event. The most recent event is recognized only at F2 (see description above), and its young age is highlighted by the freshness of the ground scarplets intercepted in the trench and in correspondence of the fault traces below. 


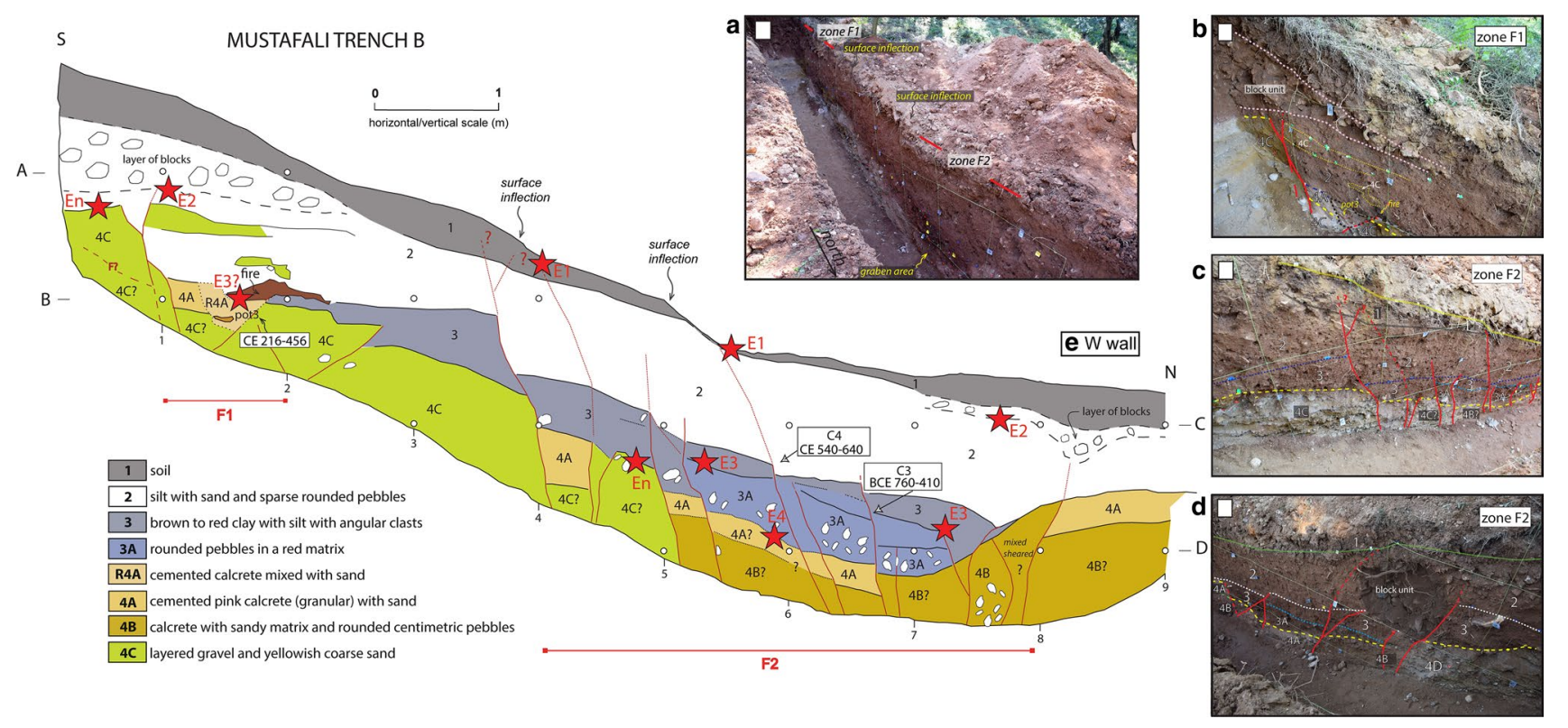

Fig. 5 Mustafali site-Trench B. a View of the W trench wall. b, c Photos of the two fault zones from the W wall (1-m grid square for scale on the walls). d Photo from the $\mathrm{E}$ wall with a detail of the fault zone F2 and an artificial hole filled by blocks. e Simplified log of the western wall from a 1:20 field logging. Triangles indicate radiocarbon

In summary, trench B shows evidence for four surface faulting events with event horizons set at different levels of the stratigraphic sequence (red stars in Fig. 5e). The age constraints for these events (Table 3) are discussed in Sect. 2.4 where we integrate the results from both trenches.

\subsection{Paleoearthquakes of the western İznik Fault}

The trenches at the Mustafali site show evidence for four surface faulting earthquakes occurred during the past about 2 millennia. Both trenches exposed two main fault zones, with apparent slip partitioning: the southernmost fault zone (F1) seems to accommodate mostly the horizontal component while the northernmost zone (F2) has a prevalent vertical component that, in this part of the fault, seems to become very important likely as the consequence of the releasing junction with the Orhangazi fault (Fig. 1). Interestingly, in both trenches the evidence for the most recent event (E1) was found only at the northernmost fault zone F2 whereas samples; rectangles contain calibrated ages of samples (Table 2). Red stars indicate location of event horizons (ground surfaces at the time of surface faulting earthquakes) labeled E1 to E4, starting from the most recent

the oldest events are seen in F1 (Figs. 4 and 5). This suggests that the fault activity is migrating toward the base of the scarp (northward) or that the "readability" of past surface faulting events is more difficult at F1 where horizontal movement prevails.

Table 3 shows the individual ages of the surface faulting earthquakes recognized in trenches $\mathrm{A}$ and $\mathrm{B}$ on the basis of the available data. Since the trenches are only about $350 \mathrm{~m}$ apart, they cross the same fault scarp, and expose correlative fault zones, it is very likely that, despite the different stratigraphy, these recorded the same surface rupture history. Therefore, we integrated the chronology from the two trenches and reconstructed the earthquake sequence of the four most recent surface faulting events at the Mustafali site (Table 3). These events should be considered a minimum as we explored only one of the fault branches that compose the fault zone at this site (Fig. 3a). Under this assumption, and given the consistency of the results from the two trenches, we constrained the age of the events by combining the age
Table 3 Earthquake history reconstructed from trenching along the CNAF

\begin{tabular}{llll}
\hline Event & Trench A & Trench B & Converging age (this work) \\
\hline Event 1 & Close to 1645-1950 CE & Much younger than 640 CE & Close to 1645-1950 CE \\
Event 2 & Younger than 620 CE & Close to 540-640 CE & 620-640 CE \\
Event 3 & Older than 775 CE & Close to 216-456 CE & Close to 216-456 CE \\
Event 4 & Much older than 620 CE & $\begin{array}{c}\text { Older than 216 CE or older than } \\
\text { 410 BCE }\end{array}$ & Pre 216 CE or pre 410 BCE \\
& & & \\
\hline
\end{tabular}


ranges from the two trenches. The most recent event (MRE) occurred close to 1645-1950 CE, the penultimate event (PEN) around 620-640 CE. The third event is set close to 216-456 CE. The oldest event predates $216 \mathrm{CE}$ or even 410BCE.

\section{Discussions}

On the basis of the interpretation of stratigraphic and structural relations in the trenches of the Mustafali site, we recognized at least four surface faulting paleoearthquakes occurred during the past 2 millennia. The morphology and size of the scarps, as well as the trench walls, indicate that several older faulting events concurred to produce the present setting. A tentative integration of the available paleoseismological results (Ikeda et al. 1989, 1991; Barka 1993; Yoshioka and Kusçu 1994; Uçarkus 2002; Doğan 2010; Özalp et al. 2013; Akyüz et al. 2014; Benjelloun 2017; Gastineau et al. 2021) and historical data (Guidoboni et al. 1994; Ambraseys 2002; Guidoboni and Comastri 2005) is reported in Fig. 6. In this figure we reported geometrical complexities in the fault trace that, along with earthquake size and dynamic, may favor rupture propagation or arrest (i.e., releasing bend at Sölöz, releasing junction south-west of İznik and releasing stepover west of Mekece).

The Most Recent Event (MRE) on the İznik segment has converging ages from most of the paleoseismological trenches opened in the area (their approximate location is shown in Fig. 6 by black dots). By merging all the data, the MRE occurred sometimes between $1700 \mathrm{CE}$ and today; therefore, it could well correlate to one of the shocks that hit the area in the 1800 s, likely the $1855 \mathrm{CE}$. This event is paleoseismologically well constrained on the Gemlik segment but it may likely have ruptured also the western part of the İznik segment, that would include also the Mustafali site (this work). Also the site investigated by Doğan (2010) in the middle of the İznik segment has evidence for this event, suggesting a longer rupture in $1855 \mathrm{CE}$ and the violation of the Sölöz releasing bend. Data from Benjelloun (2017) are derived from archaeological observations in the town of İznik, thus, they do not record surface rupture on the fault as trenches do, but they record relevant local shaking that can be produced by any nearby fault. Thus, although allowing an earthquake in the same time period, these data cannot be resolutive in the definition of the rupturing fault.

The penultimate event (PEN) is recognized in this work and also in Barka (1993). However, the uncertainties related to the ages from this latter study allows correlations also with other previous events. Good chronological correlation is also found between PEN and the archaeological evidence for damage from ground shaking acceleration found in İznik (Benjelloun 2017). In summary, this event can be correlated either to the $740 \mathrm{CE}$ historical earthquake, whose source is tentatively located in the south of Marmara Sea because it produced a tsunami, or to the $715 \mathrm{CE}$ earthquake (Guidoboni et al. 1994; Erginal et al. 2021). The equivalent $\mathrm{M}$ of 7.1 attributed to the $740 \mathrm{CE}$ historical earthquake call for a $80+\mathrm{km}$ rupture that would extend from the sea of Marmara to the western part of the İznik Fault, yielding again the violation of the Sölöz bend.

The age of the third event back, would include the $362 \mathrm{CE}$ historical event. Despite its small equivalent magnitude (Me 5.8), it is not uncommon for earthquakes with magnitude 5-6 to produce surface faulting in strike-slip environments (e.g., 1938 CE M 5.8 Kussahro earthquake and 2014 CE Mw 6.0 South Napa earthquake-Baize et al. 2019).

The oldest paleoearthquake recognized in the trenches is older than $216 \mathrm{CE}$, but it can even be older than $410 \mathrm{BCE}$, depending on the interpretation of sample $\mathrm{C} 3$ of trench $\mathrm{B}$ as reworked or in situ. If $\mathrm{C} 3$ is reworked, E4 may well coincide with the $121 \mathrm{CE}$ that is considered to have ruptured the whole İznik segment.

Archaeological evidence for a further damaging event is found in İznik between 850 and 1100 CE (Benjelloun 2017). No evidence for a paleoearthquake in this time window is found in the trenches. Interestingly, recent offshore investigations in the İznik Lake by Gastineau et al. (2021), show evidence for a faulting event and related shaking induced turbidite at 1010-1182 cal year CE (Fig. 6). This yields the 1065 earthquake, formerly considered as rupturing the SNAF (e.g., near Yenisehir), to have ruptured at least the subaqueous branch of the İznik Fault. This result highlights a further element of complexity in the İznik Fault, opening the possibility for earthquake ruptures to switch from one splay to the other during subsequent events.

Finally, no paleoseismological evidence for the 1419 CE destructive earthquake (Honkura and Işıkara 1991) was found along the İznik segment that was instead considered its source.

Although with large uncertainties on the ages of the events, paleoseismological data from the Gemlik and Geyve segments (to the west and east of the İznik segment, respectively) allow surface faulting ruptures in $1419 \mathrm{CE}$. Assuming the İzinik segment ruptured in $1419 \mathrm{CE}$ along with the Geyve and Gemlik segments, one reason for not having recognized this event in the Mustafali trenches is that the 1855 $\mathrm{CE}$ earthquake effects may have overprinted the evidence of the 1419 CE ones. No evidence for the 1419 CE earthquake was found also in the earthquake induced turbidite record (Gastineau et al. 2021) questioning its attribution to the Gemlik and Geyve segments.

As already mentioned above, there is evidence for questioning the role of the Sölöz releasing bend connecting the İznik and Gemlik faults as a permanent boundary; occasional boundary violation and rupture propagation 


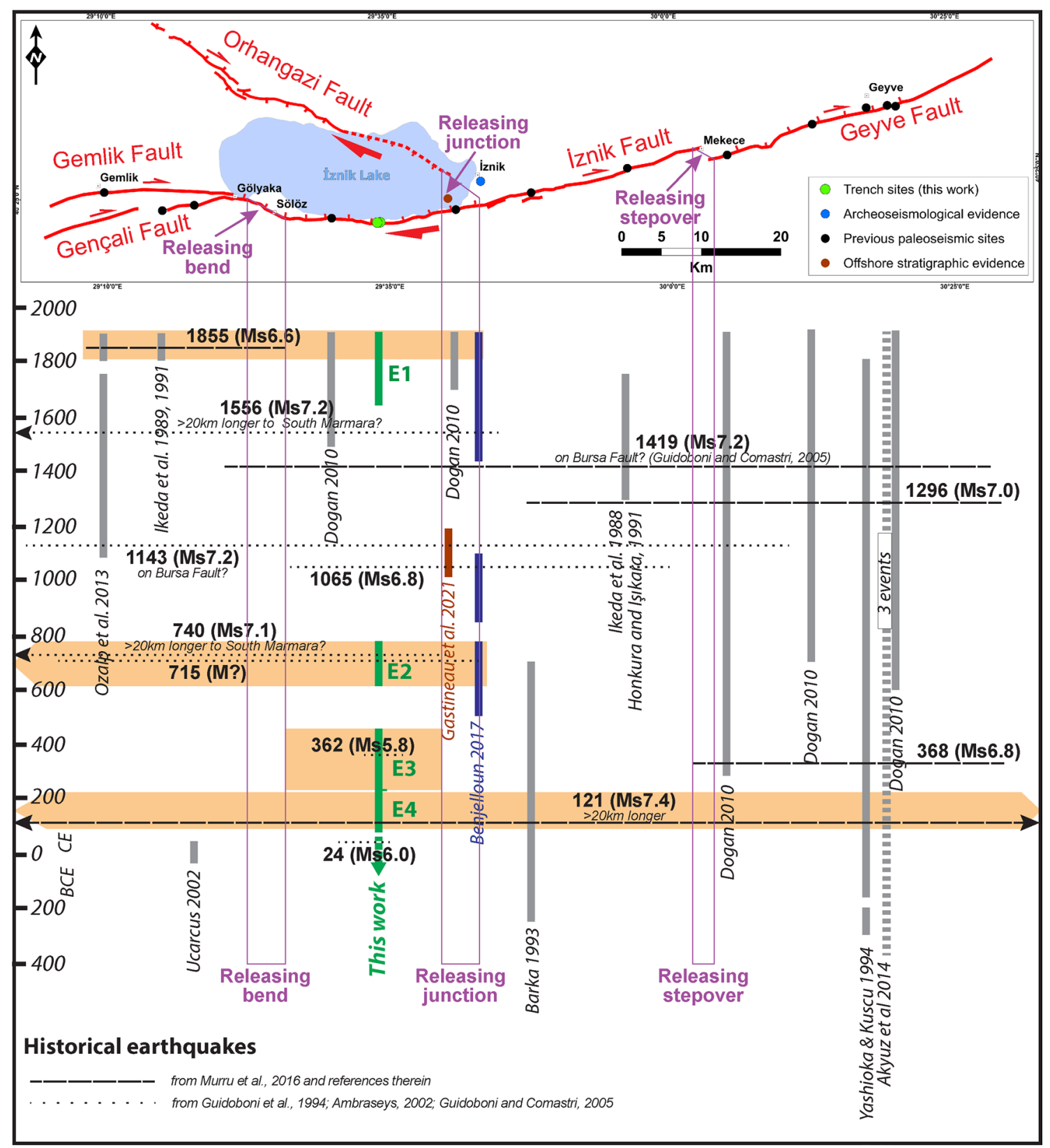

Fig. 6 Integration of paleoseismological results and historical catalogues. Light purple arrows and lines indicate segment boundaries between Gemlik, İznik and Geyve fault segments (from west to east). The green vertical lines are the age ranges of the four paleoearthquakes from this work (converging ages in Table 3). The gray vertical lines indicate the age range of occurrence of paleoearthquakes recognized by several authors at paleoseismic sites indicated as black dots in the map. The brown vertical line indicates the age range of the

between the two faults should be considered since it is dynamically possible (e.g., Oglesby et al. 2008). Conversely, the releasing junction south of İznik, seems to play a role, not only in the control of strike and kinematics of the fault but also in controlling the rupture propagation to the east. earthquake induced turbidite record. The purple vertical lines are the age ranges for relevant ground shaking events recognized on the basis of archaeological observations. The horizontal dashed and dotted lines are rupture extents (according to Wells and Coppersmith 1994) for historical earthquakes, whereas orange bands highlight the most likely ruptures of the whole İznik fault segment. This correlation cannot be traced for the oldest events (E3 and E4) due to the lack of other sites with dated paleoearthquakes

Several open questions remain about the segmentation of the CNAF in the İznik area and this has a critical impact for the inclusion of fault data in seismic hazard assessment. Extensive paleoseismological trenching and dating of faulted stratigraphy along the onshore CNAF as well as the collection of more offshore data in the İznik Lake, contain an 
incredible potential to solve the uncertainties in the location and extent of earthquake ruptures of the past and to reconstruct a reliable seismic history integrating historical, stratigraphic and paleoseismological data, of use for Seismic Hazard evaluations.

\section{Conclusions}

We performed paleoseismological investigations at the Mustafali site, along the İznik segment of the CNAF. We studied two paleoseismological trenches and have evidence for four surface faulting paleoearthquakes occurred during the past ca. 2000 years. Correlation with paleoearthquakes from nearby trenches and historical data yielded a fault rupture history for the İznik segment (Fig. 6). All the four paleoearthquakes have a likely corresponding earthquake in the historical catalogues. These are from the youngest to the oldest 1855,740 (715), 362, and possibly $121 \mathrm{CE}$. Interestingly, the $1065 \mathrm{CE}$ earthquake, not found in the trenches but in the archaeoseismological record, ruptured a recently uncovered subaqueous splay of the İznik Fault (Gastineau et al. 2021) adding to the history of earthquakes of the İznik fault segment.

Interevent times span from a few centuries to a millennium, highlighting a concentration of events during the first millennium CE. This earthquake data integration has also highlighted that the segment boundary set by several authors at the Sölöz releasing bend was occasionally violated in the past questioning the existence of persistent segment boundaries.

Finally, the large M7 + 1419 CE historical earthquake does not appear in any of the paleoseismological sites along the İznik Fault (Fig. 6) nor in the subaqueous record (Gastineau et al. 2021). One possibility for this lack is that the $1855 \mathrm{CE}$ earthquake may have overwritten the geological evidence of this previous event however, because 1419 $\mathrm{CE}$ is much larger than $1855 \mathrm{CE}$ this hypothesis seems quite improbable. At any rate, this unfit between paleoseismological, stratigraphic, and historical data is calling for extensive trenching and offshore campaigns coupled with a new review of the historical data to tighten large earthquakes to their rupturing faults.

Funding Open access funding provided by Istituto Nazionale di Geofisica e Vulcanologia within the CRUI-CARE Agreement. This work has been mostly supported by the MARSite (Marmara Supersite) "New Directions in Seismic Hazard Assessment through Focused Earth Observation in the Marmara Supersite" European Integrated Project, ENV.2012.6.4-2 (long-term monitoring experiment in geologically active regions of Europe prone to natural hazards: the Supersite concept), grant agreement 308417, Work Package 7: Re-evaluation of the seismo-tectonics of the Marmara Region. All data are freely available from the authors.

\section{Declarations}

Conflict of interest On behalf of all authors, the corresponding author states that there is no conflict of interest.

Open Access This article is licensed under a Creative Commons Attribution 4.0 International License, which permits use, sharing, adaptation, distribution and reproduction in any medium or format, as long as you give appropriate credit to the original author(s) and the source, provide a link to the Creative Commons licence, and indicate if changes were made. The images or other third party material in this article are included in the article's Creative Commons licence, unless indicated otherwise in a credit line to the material. If material is not included in the article's Creative Commons licence and your intended use is not permitted by statutory regulation or exceeds the permitted use, you will need to obtain permission directly from the copyright holder. To view a copy of this licence, visit http://creativecommons.org/licenses/by/4.0/.

\section{References}

AFAD (2020) 1900 - 20xx Earthquake Catalog (M >=4.0), https:// deprem.afad.gov.tr/depremkatalogu?lang=en. Last accessed 04/03/2021

Akyüz S, Dogan B, Aksoy ME, Tigli O, Zabci C (2014) Preliminary Paleoseismological results of the Middle Strand of the North Anatolian Fault (NAF) in the Marmara Region, NW Turkey. Geophys Res Abstracts 16:EGU2014-451

Ambraseys N (2002) The seismic activity of the Marmara Sea region over the last 2000 years. Bull Seismol Soc Am 92(1):1-18

Ambraseys N (2009) Earthquakes in the Mediterranean and Middle East. A multidisciplinary study of seismicity up to 1900. Cambridge University Press, Cambridge

Ambraseys N, Finkel C (1991) Long-term seismicity of Istanbul and of the Marmara Sea region. Terra Nova 3(5):527-539

Ambraseys N, Jackson J (1998) Faulting associated with historical and recent earthquakes in the Eastern Mediterranean region. Geophys J Int 133(2):390-406

Armijo R, Meyer B, Navarro S, King G, Barka A (2002) Asymmetric slip partitioning in the Sea of Marmara pull-apart: a clue to propagation processes of the North Anatolian Fault? Terra Nova 14(2):80-86

Baize S, Nurminen F, Sarmiento A, Dawson T, Takao M, Scotti O, Azuma T, Boncio P, Champenois J, Cinti FR, Civico R, Costa C, Guerrieri L, Marti E, McCalpin J, Okumura K, Villamor P (2019) A worldwide and unified database of surface ruptures (SURE) for fault displacement hazard analyses. Seismol Res Lett 91(1):499520. https://doi.org/10.1785/0220190144

Bargu S (1982) The geology of Iznik-Yenisehir (Bursa) Osmaneli (Bilecik) area. Istanbul Earth Sci Rev 3(1-2):191-234

Barka A (1992) The North Anatolian fault zone. Ann Tectonicae 6:164-195

Barka A (1993) Kuzey Anadolu Fayı'nın Sapanca-Izmit ve GeyveIznik Kolları üzerinde Paleosismik Arastırmalar. Technical report, TÜBITAK, Istanbul. Proje No:YBAG- 4/7551.

Barka A (1996) Slip distribution along the North Anatolian fault associated with the large earthquakes of the period 1939 to 1967. Bull Seismol Soc Am 86(5):1238-1254 
Barka A, Kadinsky-Cade K (1988) Strike-slip fault geometry in Turkey and its influence on earthquake activity. Tectonics 7(3):663-684

Benjelloun Y (2017) The middle strand of the North Anatolian fault in Iznik region: insights from geomorphology and archeoseismology. $\mathrm{PhD}$ Thesis, Université Grenoble Alpes

Carobene L, Cirrincione R, De Rosa R, Gueli AM, Marino S, Troja SO (2006) Thermal (TL) and optical stimulated luminescence (OSL) techniques for dating Quaternary colluvial volcaniclastic sediments: an example from the Crati Basin (Northern Calabria). Quat Int 148(1):149-164

Choi JH, Kim JW, Murray AS, Hong DG, Chang HW, Cheonga CS (2009) OSL dating of marine terrace sediments on the southeastern coast of Korea with implications for Quaternary tectonics. Quat Int 199(1-2):3-14

Christie-Blick N, Biddle KT (1985) Deformation and basin formation along strike-slip faults, in strike-slip deformation, basin formation and sedimentation. In: Biddle KT, Christie-Blick N (eds) Soc. Econ. Paleont. Min. Spec. Publ. pp 1-34

Doğan B (2010) Kuzey Anadolu Fay Sistemi Güney Kolunun Geyve-Gemlik Arasindaki Kesiminin Morfotektonik, Tektonostratigrafik ve Paleosismolojik Evrimi. PhD thesis, Istanbul Teknik Üniversitesi.

Doğan B, Tüysüz O, Şanlı FB (2014) Tectonostratigraphic evolution of the basins on the southern branch of the North Anatolian Fault System in the SE Marmara Region, Turkey. Int J Earth Sci (Geol Rundsch) 104:389-418. https://doi.org/10.1007/s00531-0141083-9 (2015)

Duller GAT (2008) Single-grain optical dating of Quaternary sediments: why aliquot size matters in luminescence dating. Boreas 37:589-612

Emre Ö, Erkal T, Tchepalyga A, Kazancı N, Keçer M, Ünay E (1998) Neogene-quaternary evolution of the Eastern Marmara Region, Northwest Turkey. Bull Miner Res Explor 120:119-145

Emre Ö, Doğan A, Duman TY, Özalp S (2011) 1:250.000 Ölçekli Türkiye Diri Fay Haritası Serisi, Bursa (NK 35-12) Paftası. Seri No: 9, Maden Tetkik ve Arama Genel Müdürlüğü, Ankara

Emre Ö, Duman TY, Özalp S, Şaroğlu F, Olgun Ş, Elmacı H, Çan $\mathrm{T}$ (2018) Active fault database of Turkey. Bull Earthq Eng 16(8):3229-3275. https://doi.org/10.1007/s10518-016-0041-2

Erginal AE, Erenoğlu RC, Yıldırım C, Selim HH, Kıyak NG, Erenoğlu O, Ulugergerli E, Karabıyıkoğlu M (2021) Co-seismic beachrock deformation of 8th century AD Earthquake in Middle Strand of North Anatolian Fault, Lake Iznik, NW Turkey. Tectonophysics 799:228690. https://doi.org/10.1016/j.tecto.2020.228690 (ISSN 0040-1951)

Ergintav S, Reilinger R, Çakmak R, Floyd M, Cakir Z, Doğan U et al (2014) Istanbul's earthquake hot spots: geodetic constraints on strain accumulation along faults in the Marmara seismic gap. Geophys Res Lett 41(16):5783-5788

Flerit F, Armijo R, King GCP, Meyer B, Barka A (2003) Slip partitioning in the Sea of Marmara pull-apart determined from GPS velocity vectors. Geophys J Int 154(1):1-7

Flerit F, Armijo R, King GCP, Meyer B (2004) The mechanical interaction between the propagating North Anatolian Fault and the backarc extension in the Aegean, Earth Planet. Sci Lett 224:347-362

Fuchs M, Lang A (2001) OSL dating of coarse-grain fluvial quartz using single aliquot protocols on sediments from NE-Peloponnese. Greece Quat Sci Rev 20:783-787

Gasperini L, Polonia A, Çağatay MN, Bortoluzzi G, Ferrante V (2011) Geological slip rates along the North Anatolian Fault in the Marmara region. Tectonics 30:TC6001. https://doi.org/10.1029/2011T C002906

Gastineau R, de Sigoyer J, Sabatier P, Fabbri SC, Anselmetti FS, Develle AL et al (2021) Active subaquatic fault segments in Lake Iznik along the middle strand of the North Anatolian Fault, NW
Turkey. Tectonics 40:e2020TC006404. https://doi.org/10.1029/ 2020TC006404

Guidoboni E, Comastri A (2005) Catalogue of earthquakes and tsunamis in the mediterranean area from the 11th to the 15th century. Ist. Naz. di Geophys. e Vulcanol, p 1037

Guidoboni E, Comastri A, Traina G (1994) Catalogue of ancient earthquakes in the Mediterranean area up to the 10th century. Istituto Nazionale di Geofisica

Hergert T, Heidbach O (2010) Slip-rate variability and distributed deformation in the Marmara Sea fault system. Nat Geosci $3(2): 132-135$

Hergert T, Heidbach O, Becel A, Laigle M (2011) Geomechanical model of the Marmara Sea region-I. 3-D contemporary kinematics. Geophys J Int 185(3):1073-1089. https://doi.org/10.1111/j. 1365-246X.2011.04991.X

Honkura Y (1991) Işıkara AM (1991) Multidisciplinary research on fault activity in the western part of the North Anatolian Fault Zone. Tectonophysics 193(4):347-357. https://doi.org/10.1016/ 0040-1951(91)90343-Q

Ikeda Y, Suzuki Y, Herece E (1989) Late Holocene activity of the North Anatolian fault zone in the Orhangazi plain, northwestern turkey. In: Honkura Y, Isikara AM (eds) Multidisciplinary research on fault activity in the western part of the North Anatolian fault zone (2), vol 2. Tokyo Institute of Technology, pp $16-30$

Ikeda Y, Herece E, Sugai T, Isikara AM (1991) Postglacial crustal deformation associated with slip on the western part of the North Anatolian Fault Zone in the Iznik Lake Basin, Turkey. Bull Department Geogr Univ Tokyo 23:13-23

Kalafat D, Güneş Y, Kekovalı K, Kara M, Deniz P, Yılmazer M (2011) Bütünleştirilmiş Homojen Türkiye Deprem Kataloğu (19002010); $M \geq 4.0$ ). Boğaziçi Üniversitesi, Kandilli Rasathanesi ve Deprem Araştırma Enstitüsü, Yayın No: 1049, 640 s., Bebek-İstanbul

Koçyiğit A (1988) Tectonic setting of the Geyve basin: age and total displacement of Geyve fault zone. Middle East Tech Univ J Pure Appl Sci 21:81-104

Kürçer A, Chatzipetros A, Tutkun SZ, Pavlides S, Özkan A, Valkaniotis S (2008) The Yenice-Gönen active fault (NW Turkey): active tectonics and palaeoseismology. Tectonophysics 453(1):263-275

Kuşçu İ, Okamura M, Matsuoka H, Yamamori K, Awata Y, Özalp $S$ (2009) Recognition of active faults and stepover geometry in Gemlik Bay, Sea of Marmara, NW Turkey. Mar Geol 260:90-101

McClusky S, Balassanian S, Barka A, Demir C, Ergintav S, Georgiev I, Gurkan O, Hamburger M, Hurst K, Kahle H, Kastens K, Kekelidze G, King R, Kotzev V, Lenk O, Mahmoud S, Mishin A, Nadariya M, Ouzounis A, Paradissis D, Peter Y, Prilepin M, Reilinger R, Sanli I, Seeger H, Tealeb A, Toksöz MN, Veis G (2000) Global Positioning System constraints on plate kinematics and dynamics in the eastern Mediterranean and Caucasus. $\mathbf{J}$ Geophys Res 105(B3):5695-5719

McKenzie DP (1972) Active tectonics of the mediterranean region. Geophys J Roy Astron Soc 30(2):109-185

McKenzie DP (1978) Active tectonics of the Alpine-Himalayan belt: the Aegean Sea and surrounding regions. Geophys J R Astron Soc 55:217-254

Meade BJ, Hager BH, McClusky SC, Reilinger RE, Ergintav S, Lenk O, Barka A, Özener H (2002) Estimates of Seismic Potential in the Marmara Sea region from block models of secular deformation constrained by global positioning system measurements. Bull Seismol Soc Am 92(1):208-215

Murray AS, Wintle AG (2000) Luminescence dating of quartz using an improved single-aliquot regenerative-dose protocol. Radiat Meas 32(1):57-73 
Murray AS, Wintle AG (2003) The single aliquot regenerative dose protocol: potential for improvements in reliability. Radiat Meas 37:377-381

Murru M, Akinci A, Falcone G, Pucci S, Console R, Parsons T (2016) M 7 earthquake rupture forecast and time-dependent probability for the sea of Marmara region, Turkey. J Geophys Res 121(4):2679-2707

Oglesby DD, Mai PM, Atakan K, Pucci S (2008) Dynamic models of earthquakes on the North Anatolian fault zone under the Sea of Marmara: effect of hypocenter location. Geophys Res Lett. https:// doi.org/10.1029/2008GL035037

Özalp S, Emre Ö, Dogan A (2013) The segment structure of southern branch of the North Anatolian Fault and Paleoseismological behaviour of the Gemlik fault, NW Anatolia. Bull MTA 147:1-17

Özcan Z, Okay A, Özcan E, Hakyemez A, Altiner S (2012) Late Cretaceous-Eocene geological evolution of the Pontides based on new stratigraphic and palaeontologic data between the Black Sea coast and Bursa (NW Turkey). Turkish J Earth Sci 21(6):933-960

Öztürk K, Yaltırak C, Alpar B (2009) The Relationship between the tectonic setting of the Lake İznik Basin and the Middle Strand of the North Anatolian Fault. Turkish J Earth Sci 18:209-224

Pantosti D, Pucci S, Palyvos N, De Martini PM, Daddezio G, Collins PEF, Zabci C (2008) Paleoearthquakes of the Düzce fault (North Anatolian Fault Zone): insights for large surface faulting earthquake recurrence. J Geophys Res 113:1309. https://doi.org/10. 1029/2006JB004679

Pucci S, De Martini PM, Pantosti D (2008) Preliminary slip rate estimates for the Düzce segment of the North Anatolian Fault Zone from offset geomorphic markers. Geomorphology 97(3-4):538554. https://doi.org/10.1016/j.geomorph.2007.09.002 (ISSN 0169-555X)

Pucci S, Pantosti D, De Martini PM (2010) Earthquake recurrence of the Düzce fault (North Anatolian Fault Zone): integrating geomorphological and paleoseismological analyses. In: Guarnieri P (ed) Recent progress on earthquake geology. Nova Science Publishers, $\mathrm{p} 257$

Reilinger RE, McClusky SC, Oral MB, King RW, Toksoz MN, Barka AA, Kinik I, Lenk O, Sanli I (1997) Global Positioning System measurements of present-day crustal movements in the Arabia-Africa-Eurasia plate collision zone. J Geophys Res 102(B5):9983-9999

Reilinger RE, McClusky SC, Vernant P, Lawrence S, Ergintav S, Cakmak R, Ozener H, Kadirov F, Guliev I, Stepanyan R, Nadariya M, Hahubia G, Mahmoud S, Sakr K, ArRajehi A, Paradissis D, AlAydrus A, Prilepin M, Guseva T, Evren E, Dmitrotsa A, Filikov SV, Gomez F, Al-Ghazzi R, Karam G (2006) GPS constraints on continental deformation in the Africa-Arabia-Eurasia continental collision zone and implications for the dynamics of plate interactions. J Geophys Res 111(B5):B05411
Şaroğlu F, Emre Ö, Kuşçu İ (1992) Turkiye Diri Fay Haritası (Active Fault Map of Turkey), scale 1:2,000,000, one sheet. General Directorate of Mineral Research and Exploration (MTA), Ankara

Selim HH, Tüysüz O, Karakaş A, Taş KÖ (2013) Morphotectonic evidence from the southern branch of the North Anatolian Fault (NAF) and basins of the south Marmara sub-region, NW Turkey. Quat Int 292:176-192. https://doi.org/10.1016/j.quaint.2012.11. 022 (ISSN 1040-6182)

Sengör A, Tüysüz O, Imren C, Sakınç M, Eyidogan H, Görür N, Pichon XL, Rangin C (2005) The North Anatolian fault: a new look. Annu Rev Earth Planet Sci 33(1):37-112

Stevens T, Armitage SJ, Lu H, Thomas DSG (2007) Examining the potential of high sampling resolution OSL dating of Chinese loess. Quat Geochronol 2(1-4):15-22

Straub C, Kahle HG, Schindler C (1997) GPS and geologic estimates of the tectonic activity in the Marmara Sea region, NW Anatolia. J Geophys Res 102(B12):27587-27601

Taymaz T, Jackson J, McKenzie D (1991) Active tectonics of the north and central Aegean Sea. Geophys J Int 106:433-490. https://doi. org/10.1111/j.1365-246X.1991.tb03906.x

Tsukuda E, Herece E, Kuşçu İ (1988) Some geological evidence on activity of the western North Anatolian fault, Geyve, İznik, Gemlik area, research on Quaternary crustal movement and earthquake prediction. Report of International Research and Development Cooperation ITIT Project, 8513, Tokyo, pp 69-91

Uçarkus G (2002) Gemlik Fay Zonunun Aktif Tektonigi [Active Tectonics of Gemlik Fault Zone]. Msc thesis, ITÜ Avrasya Yerbilimleri Enstitüsü. (in Turkish with English abstract, unpublished)

Wells DL, Coppersmith KJ (1994) New empirical relationships among magnitude, rupture length, rupture width, rupture area, and surface displacement. Bull Seismol Soc Am 84(4):974-1002

Wintle AG, Murray AS (2000) Quartz OSL: effects of thermal treatment and their relevance to laboratory dating procedures. Radiat Meas 32:387-400

Woodcock NH, Fischer M (1986) Strike-slip duplexes. J Struct Geol 8(7):725-735. https://doi.org/10.1016/0191-8141(86)90021-0 (ISSN 0191-8141)

Yılmaz Y, Genç C, Yi`gitbas E, Bozcu M, Yılmaz K (1995) Geological evolution of the late Mesozoic continental margin of Northwestern Anatolia. Tectonophysics 243(1):155-171

Yoshioka T, Kusçu I (1994) Late Holocene faulting events on the IznikMekece fault in the western part of the North Anatolian fault zone, Turkey. Bull Geol Surv Jpn 45(11):677-685

Publisher's Note Springer Nature remains neutral with regard to jurisdictional claims in published maps and institutional affiliations. 